\title{
Participation Constraints in the Stock Market Evidence from Unexpected Inheritance due to Sudden Death
}

Andersen, Steffen; Meisner Nielsen, Kasper

Document Version

Final published version

Publication date:

2010

\section{License \\ CC BY-NC-ND}

Citation for published version (APA):

Andersen, S., \& Meisner Nielsen, K. (2010). Participation Constraints in the Stock Market: Evidence from Unexpected Inheritance due to Sudden Death. Department of Economics. Copenhagen Business School. Working Paper / Department of Economics. Copenhagen Business School No. 3-2010

Link to publication in CBS Research Portal

\section{General rights}

Copyright and moral rights for the publications made accessible in the public portal are retained by the authors and/or other copyright owners and it is a condition of accessing publications that users recognise and abide by the legal requirements associated with these rights.

Take down policy

If you believe that this document breaches copyright please contact us (research.lib@cbs.dk) providing details, and we will remove access to the work immediately and investigate your claim. 
Copenhagen

Business School

\section{Department of Economics}

Copenhagen Business School

Working paper 3-2010

\section{PARTICIPATION CONSTRAINTS IN THE STOCK MARKET: Evidence from Unexpected Inheritance due to Sudden Death}

\section{Steffen Andersen Kasper Meisner Nielsen}




\title{
Participation Constraints in the Stock Market:
}

\section{Evidence from Unexpected Inheritance due to Sudden Death ${ }^{*}$}

\author{
Steffen Andersen \\ Copenhagen Business School \\ sa.eco@cbs.dk \\ Kasper Meisner Nielsen \\ Hong Kong University of Science and Technology \\ nielsen@ust.hk
}

\section{August 2010}

Abstract: We use a natural experiment to investigate the impact of participation constraints on individuals' decisions to invest in the stock market. Unexpected inheritance due to sudden deaths results in exogenous variation in financial wealth and allows us to examine whether fixed entry and ongoing participation costs cause non-participation. We have three key findings. First, windfall wealth has a positive effect on participation. Second, the majority of households do not react to sizeable windfalls by entering the stock market, but hold on to substantial safe assets - even over longer horizons. Third, the majority of households inheriting stock holdings actively sell the entire portfolio. Overall, these findings suggest that participation by many individuals is unlikely to be constrained by financial participation costs.

JEL Classifications: E2, D8, G1

Keywords: Stock Market Participation, Household Finance, Portfolio Choice, Sudden Death, Inheritance.

* We thank Thea Y. Jensen for excellent research assistance. We thank an anonymous referee, Jiayi Balasuriya, Kalok Chan, François DeGeorge, Bruce Grundy, Glenn W. Harrison, Hung Wan Kot, Elizabeth E. Rutsröm, Johan Sulaeman, Lise Vesterlund and seminar participants at 2010 China International Conference in Finance, Hong Kong Finance Workshop 2009, Koc University, University of Hong Kong, University of Lugano, University of Melbourne, University of Zurich and the Workshop on Household, Risk and Insurance at Paris Dauphine University for helpful comments and suggestions.

Corresponding Author: Kasper Meisner Nielsen, Department of Finance, Hong Kong University of Science and Technology, Clear Water Bay, Hong Kong SAR, China. Email: nielsen@ust.hk 
Few households participate-directly, or through mutual funds—in the stock market. In the absence of participation constraints, this non-participation is puzzling, as standard models of lifetime consumption and portfolio choice predict that all households, no matter how risk averse, should invest in stocks [Samuelson (1969), Merton (1969, 1971), and Arrow (1974)]. In this study, we use a natural experiment to test whether nonparticipation is caused by participation costs. Exogenous variations in wealth result from unanticipated inheritance due to sudden death, and allow us to identify whether individuals face participation constraints in the stock market. Our results reveal that nonparticipation for the majority of households is unlikely to be explained by financial constraints.

At present, the leading explanation for non-participation in the stock market is fixed entry or ongoing participation costs of some kind. These costs capture anything from transaction costs to time spent on information gathering and preparation of tax returns. ${ }^{1}$ Such pecuniary costs can explain non-participation simply because many households have insufficient wealth to make participation worthwhile. For instance, Vissing-Jørgensen (2002) demonstrates that a moderate per-period cost of 50 USD (260 USD) in year 2000 prices is sufficient to explain why half (three-quarters) of non-stockholders in the United States do not participate. ${ }^{2}$ Empirical studies invariably find a strong positive correlation between wealth and stock market participation, which in turn is interpreted as evidence of participation costs.

Alternatively, fixed costs may be an economist's pecuniary representation of behavioral and psychological factors that make equity ownership uncomfortable for some households. Although economic, behavioral, and psychological explanations are likely to

\footnotetext{
1 Prior literature provides a myriad of examples of fixed (pecuniary) costs, but no stringent definition. Examples include trading costs, one-time learning costs, and time and money spent on everything from keeping up with market developments and choosing and monitoring portfolio investments, to filing out tax forms. Fixed entry costs are one-time outlays related to entering the stock market, whereas participation costs are expenses related to staying in the market.

2 Vissing-Jørgensen (2002) estimates the fixed per-period cost by calculating the benefit of stock market participation given observed individual financial wealth and an after-tax equity premium of 5.6 percent.
} 
coincide, prior literature has not been able to identify the relative importance of these explanations for non-participation. Consequently, the inability to pinpoint source(s) of non-participation makes it difficult to promote wider stock ownership. In essence, the fixed-cost explanation requires more involved economic policies aimed at lowering the costs to facilitate participation, whereas financial education might limit the effect of behavioral and psychological barriers.

In this paper we use a natural experiment to formally test whether fixed entry and ongoing participation costs cause non-participation. We use windfall wealth from unexpected inheritance due to sudden death as a plausible source of exogenous variation to identify how these frictions explain non-participation. If fixed entry and participation costs restrict participation, we should expect individuals to respond to windfall wealth by entering the stock market. If, however, behavioral, cognitive, and psychological explanations are at play, even sizeable windfalls will have little impact on participation.

Our empirical identification strategy relies on a conservative medical definition of sudden death and unique cause-of-death data from official death certificates to identify 10,344 cases from 346,788 deaths in Denmark over a period of six years. Each case is classified as medically unexpected and sudden as well as having resulted in the termination of the household, potentially increasing the beneficiary's wealth. While constituting tragic events, these sudden deaths help us to identify 17,191 beneficiaries who have received a windfall. To the best of our knowledge, this is the first study that seeks to examine barriers to stock market participation using exogenous variation from one of nature's own experiments.

The advantage of our identification strategy is fourfold. First, as windfall wealth from unexpected inheritance is unrelated to current economic and stock market conditions, it is reasonable to attribute a positive effect of inherited wealth on stock market participation as evidence of the existence of fixed participation costs. Second, by exploiting the variation in the characteristics of beneficiaries, we can enhance our understanding of fixed 
entry and ongoing participation costs. In particular, we are interested in examining whether the effect of windfall wealth is larger for individuals who the prior literature has identified as having low entry and participation costs. Third, detailed information on the composition of inherited wealth allows us to identify the effect of procrastination by decomposing inherited wealth into inherited stocks and inherited cash. Inheriting an estate that holds stocks alters the active decision from one of choosing to enter the stock market to one of choosing to exit it. If procrastination drives non-participation, we should expect to find an additional effect on participation of inheriting a dollar's worth of stock as compared to the effect of inheriting the same value in cash. Fourth, our strategy allows us to control for unobserved individual characteristics (e.g., ability and social heritage) that are likely to correlate with income and wealth.

Although our empirical identification relies on deaths that medical records classify as sudden and unexpected, we cannot exclude the possibility that some deaths might have been anticipated by the immediate family. To address this concern, we provide a robustness check that focuses exclusively on accidents, in which death is less predictable.

Our results reveal that some individuals face entry and ongoing participation costs in the stock market. Receiving a windfall of one million Danish kroner (DKR), equivalent to 134,000 Euro, raises an individual's probability of entering the stock market within the following three years by approximately 21 percentage points, still leaving the majority of individuals as non-participants.

We further analyze the time window to determine whether these results are driven by investment inertia caused by individuals slowly reallocating their portfolios. Even though some individuals delay entry, we find that the vast majority of entrants invest in the stock market within three years. While our results document the existence of entry and participation costs in the stock market, they also show that a surprisingly large fraction of individuals who receive considerable windfalls continue not to participate- 
even over longer horizons. These surprising observations hold even for highly educated and financially literate individuals who possess knowledge about the stock market. Still, among these individuals, a large fraction stays out of the stock market after receiving a sizeable windfall.

We also examine the contention, made in much literature, that procrastination is an important factor in understanding individuals' often inadequate savings for retirement. Procrastination might cause low stock market participation if individuals neglect to invest out of carelessness or laziness. We test the impact of procrastination by analyzing the effect of inheriting stocks rather than cash. Because the fixed entry costs of participation are reasonably similar in the two cases, any difference in participation rates can largely be attributed to the effect of procrastination. ${ }^{3}$ Among households that inherit stock holdings, the majority of individuals actively exit the stock market by selling the entire position. This finding limits the viability of participation costs as the leading explanation for the participation puzzle.

Finally, we document that, post-inheritance, non-participants keep a substantial fraction of their inheritance in financial assets. Financial wealth in bonds and in cash, in particular, increases significantly following inheritance. Households who receive a windfall of at least one million DKR, keep on average 512,000 DKR (68,700 Euro) in financial wealth. Thus, non-participants choose to forego participation benefits that are large enough to compensate for fixed entry costs. Overall, our results demonstrate that although fixed entry and participation costs exist, they are unlikely to explain why the majority of households are non-participants.

Understanding the barriers to participation offers better insight into why individuals shy away from the stock market. This insight is important because limited participation

\footnotetext{
3 The difference in the fixed cost of inheriting cash to that of inheriting stocks relates to the difference between initial transaction costs and transfer fees associated with moving the stocks from the estate to the beneficiary's brokerage account. As any difference between these costs account for a trivial fraction of the total fixed costs, it seems reasonable to assume that differences in fixed entry costs are independent of whether an individual inherits cash or stock.
} 
has serious implications for economic welfare, financial markets, and an individual's expected lifetime income and consumption. Stock market participants enjoy higher lifetime consumption [Mankiw and Zeldes (1991)], and foregone consumption often exceeds $2 \%$ of annual consumption [Cocco, Gomes, and Maenhout (2005)]. The lower expected lifetime consumption persists even when taking into account that many nonparticipants would likely be inefficient investors who incur lower returns [Calvet, Campbell, and Sodini (2007)]. As pointed out by Campbell (2006), a better understanding of the participation constraints also helps us evaluate whether individuals make investment mistakes and whether financial educators can reduce the incidence and welfare costs of such mistakes. On this important issue, our results show that although fixed participation costs keep some individuals out of the stock market, a vast majority of individuals do not respond to significant windfall wealth. For those individuals, other barriers such as behavioral, cognitive, and psychological constraints are likely to dominate.

The rest of the paper proceeds as follows. Section 2 describes the motivation and background of the paper; Section 3 outlines our data and presents summary statistics and our empirical strategy; Section 4 presents the results of the paper; Section 5 provides robustness checks using alternative specifications; and Section 6 concludes.

\section{Motivation and Background}

In the standard models of lifetime consumption and portfolio choice, an individual's lifetime utility is maximized by choosing consumption and by holding a mix of safe and risky assets [Samuelson (1969), Merton (1969, 1971), and Arrow (1974)]. A central result, in these models, is that all individuals should invest in the same portfolio of risky assets, with the individual's risk aversion determining the actual allocation between risky and safe assets. The standard models, therefore, predict that it is optimal for all individuals to hold a least a fraction of stocks in their portfolio and, thus, participate in the stock market. 
In contrast, it has long been observed empirically that stock market participation is far from universal [Blume and Friend (1974, 1978), King and Leape (1984), Mankiw and Zeldes (1991)]. Although participation varies greatly across countries and has increased recently [Guiso, Haliassos, and Japelli (2003), Giannetti and Koskinen (2005)], the overall impression is that participation is still low [Campbell (2006)]. As the observed limited participation contrasts with the theoretical predictions of the standard models, it follows that this discrepancy points to a failure in one of the underlying assumptions.

Non-participation has generally been explained by moderate fixed costs related to entry and ongoing participation [Haliassos and Bertaut (1995), and Vissing-Jørgensen (2002, 2003)]. Such fixed costs capture time and money spent in order to invest in the stock market. These time and money costs may include any costs related to learning about stocks, acquiring information, trading, monitoring the portfolio, or preparing tax forms, which tend to become more complicated with equity ownership. Examining the magnitude of these costs, Vissing-Jørgensen (2002) demonstrates that a per-period cost of 50 USD (260 USD) in 2000 prices is enough to explain why half (three-quarters) of nonstockholders do not participate: simply because these individuals have insufficient financial wealth to make it worthwhile. While this result is not based on a formal test for the presence of such fixed costs, it does provide an economic estimate of whether participation costs are a likely explanation of limited participation. Fixed costs, however, cannot explain non-participation among wealthy households.

Several preexisting studies have demonstrated cross-sectional variation in stock market participation in keeping with the fixed-cost argument. In particular, participation is generally increasing with wealth, age, and education [see Mankiw and Zeldes (1991), Haliassos and Bertaut (1995), Bertaut (1998), Poterba and Samwick (1999), Guiso et al. (2003), Vissing-Jørgensen (2003)]. If participation is costly, it should increase with wealth because larger portfolios are more likely to be able to incur such costs. Moreover, the fixed-cost argument also predicts that the population of participants should be older than 
non-participants because individuals will continue to participate once a fixed entry cost has been paid. ${ }^{4}$ Because of their knowledge and lower information costs, highly educated individuals are generally perceived as having lower fixed costs and, hence, higher participation. ${ }^{5}$ In addition, prior literature has also demonstrated a strong dependence in the decision to hold stocks over time, which is consistent with the existence of fixed entry costs [Vissing-Jørgensen (2003)].

Fixed costs may be, as pointed out by Campbell (2006), the economist's representation of individual characteristics or psychological factors that make equity ownership uncomfortable for some households. Through theoretical and empirical analyses, several psychological explanations for non-participation have emerged. Many of these contributions focus on the individual's aversion to the uncertain outcomes of gambling, such as ambiguity aversion [Knox (2003)], loss aversion [Ang, Bakaert, and Lui (2005), and Dimmock (2005)] and loss aversion combined with narrow framing [Barberis, Huang, and Thaler (2006)]. Other studies have focused on behavioral or psychological factors, such as an individual's (over-) optimism [Puri and Robinson (2005)], subjective assessment of stock market performance [Biais, Bossaerts, and Spatt (2004), and Dominitz and Manski (2005)], lack of trust in financial markets [Guiso, Sapienza, and Zingales (2008)], and (low) experienced stock returns [Malmendier and Nagel (2009)]. More recently, Christelis, Jappelli, and Padula (2009), and Grinblatt, Keloharju, and Linnainmaa (2009) have documented a positive relation between participation and intelligence. According to these studies, non-participation is an investment mistake that households with high fixed costs are more likely to make. In a related study, Hong, Kubik, and Stein (2004) find that social households are more likely to invest due to peer effects.

\footnotetext{
${ }^{4}$ If one studies the entry decision, the fixed entry cost argument implies that younger individuals, ceteris paribus, should be more likely to enter the stock market because they can benefit from participation over a longer horizon.

${ }^{5}$ Consistent with findings of lower fixed costs for educated individuals, Christiansen, Joensen, and Rangvid [2008] show that economists are more likely to participate in the stock market. In related results, Calvet, Campbell, and Sodini (2009) show that financially sophisticated investors are more likely to enter and less likely to exit the stock market.
} 
Even though considerable empirical evidence suggests that fixed costs and psychological barriers explain non-participation, prior empirical literature has relied mainly on cross-sectional variation, which makes difficult convincingly controlling for individual heterogeneity and separating the fixed costs argument from the behavioral and psychological explanations. Although several studies have used panel data in an attempt to overcome these problems [e.g., Guiso, Haliassos, and Jappelli (2001), Vissing-Jørgensen (2003), and Calvet, Campbell, and Sodini (2007, 2009)], changes in income and wealth are unlikely to be random. As a result, it is difficult to establish whether the positive income and wealth effects on participation are caused by fixed costs or omitted factors, such as unobservable individual characteristics, or by macroeconomic trends that affect income, wealth, and investment opportunities. Moreover, in cross-sectional data, separating age effects from time and cohort effects is impossible.

Empirical identification in cross-sectional analysis is also complicated by the fact that the fixed costs and the psychological barrier arguments predict relationships that are observationally equivalent. For instance, the objective-cost argument predicts that better educated individuals should participate more because they face lower costs, whereas, according to the behavioral and psychological explanations, education makes it more likely that the household has learned that non-participation is an investment mistake. A similar argument can be made about the uncovered relation between cognitive abilities (intelligence) and participation. Thus, although prior literature has documented that education, the type of education (economics), and intelligence have a positive effect on participation, we do not know whether this is due to fixed costs or to behavioral or psychological barriers.

We use exogenous variation in wealth to overcome these concerns. Our candidate source of exogenous variation in wealth arises from unexpected inheritance due to the sudden death of an individual's parents. In terms of methodology, Brunnermeier and Nagel (2008) is the closest to our study. Brunnermeier and Nagel (2008) use panel data 
from Panel Study of Income Dynamics (PSID) surveys of U.S. households to identify the effect of changes in liquid wealth on an individual's asset allocation and show that an individuals' risk aversion is constant over time. Brunnermeier and Nagel (2008) instrument liquid wealth with quintile dummies for reported income growth and inheritance receipts to ascertain that their results are not driven by measurement errors. The instrumental variable estimation is focused on the asset allocation of participating households. We extend this line of inquiry by focusing entirely on whether stock market participation is induced by windfall wealth that results from sudden deaths. The focus on unanticipated inheritance is essential to our study, as expected inheritance cannot convincingly identify the casual relationship between fixed costs and stock market participation. In precise terms, expected inheritance is likely to have a negative bias on the effect of inherited wealth on stock market participation because terminal patients have an economic incentive to distribute wealth to beneficiaries before their deaths in order to minimize estate taxation. Thus, expected inheritance is likely to negatively bias the estimates of the relative importance of fixed entry and participation costs because we cannot observe when these transfers take place. In an effort to overcome such problems, we focus exclusively on windfall wealth from unexpected inheritance due to sudden death.

\section{Nature's Own Experiment: Windfall Wealth from Unexpected Inheritance due to Sudden Death}

Identifying exogenous variation in an individual's wealth poses a major empirical challenge. We posit that there exist at least two good candidates from hitherto unexplored sources: lottery prizes and unexpected inheritance. Although lotteries are random draws, they require participation, which introduces a potential selection bias. Unexpected inheritance resulting from sudden death, on the other hand, is a truly random experiment. Because all individuals have legal parents, no selection of individuals takes place, except by means of the death event. Thus, for this identification strategy to work, the death has to 
be unexpected and sudden. A sudden death is medically defined as an unexpected death that occurs instantaneously or within a few hours of an abrupt change in the person's previous clinical state. For instance, the American Academy of Pediatrics defines sudden cardiac death as a non-traumatic, nonviolent, unexpected event resulting from sudden cardiac arrest within six hours of a previously witnessed state of normal health. ${ }^{6}$ As sudden death is, by nature, a random draw, inheritance that results from sudden death is a natural experiment that induces exogenous variation in an individual's wealth. We consequently assemble a unique dataset from Denmark that allows us to identify windfall wealth from unexpected inheritance and relate it to stock market participation.

The possibility that, for some individuals, inheritance is anticipated, or that individuals might borrow against (even unexpected) inheritance, could appear to weaken our identification strategy. We approach these prospects the following way. To ascertain that the timing of the inheritance is unanticipated, we provide a very narrow medical definition of sudden deaths. We also note that if the size of the bequests is somewhat anticipated, previous studies underestimate household wealth and thus overstate the ability of participation costs to explain non-participation. To bolster our main argument that sudden bequests do provide an exogenous wealth shock, we interact inherited wealth with age and restrict the sample to individuals for whom the shock is more unanticipatedeither because of an accident or because both parents die suddenly within the same year. We also control for differences in anticipated bequest related to expected parental consumption (prior to death) by including parental age among the match characteristics. Collectively these results provide evidence consistent with our identification strategy.

In addition to offering unique data access, the Danish case also provides us with a legal environment that eases the identification of estates and their heirs. The Danish Inheritance Act of 1964 divides relatives into three groups: Group 1 consists of the

${ }^{6}$ American Academy of Pediatrics, Guidelines for Pediatricians: Sudden Cardiac Death (SDC), Issue 9, November 2002. 
spouse, children, and grandchildren; Group 2 contains the deceased's parents and siblings (and, secondarily, their children); and Group 3 comprises grandparents and their children. By default, relatives in Group 1 inherit the estate. If no Group 1 (2) relatives exist, the relatives in Group 2 (3) will be eligible to inherit the deceased's wealth. Within Group 1 the estate is divided, with one-third transferred to the spouse and two-thirds distributed equally among the children, unless the spouse chooses to delay the children's inheritance until her own death. Grandchildren will inherit their parent's proportional share if their parent is deceased. Similar default sharing rules exist for Group 2 and 3 relatives.

In the analysis, we focus on cases in which Group 1 relatives exist, but in which the suddenly deceased was a widow (or in rare cases, a deceased couple). We refer to these cases as termination of households, and motivate this choice by the fact that most widows choose to delay their children's inheritance until their own death. This designation also simplifies the analysis, since children by default will inherit the estate in proportional shares in all such cases. The default sharing rules can partially be offset by the existence of a will, but an offspring's entitled share of the estate cannot be reduced beneath 50 percent of the default. Moreover, opting out of the default sharing rule is extremely rare, as only $2 \%$ of the empirically relevant individuals in Denmark have drafted a will [Ret og Råd (2008)]. Consequently, the net wealth of the estates in our sample is divided equally among the offspring.

Identification of estates is facilitated by the deceased's institutional environment. Danish law requires that a doctor issue a death certificate when a citizen dies. If the person dies at home, the death certificate is filled out by the personal doctor or the emergency doctor on duty (Lagevagten). If the person dies in the hospital, a doctor at the hospital will issue the death certificate. Danish law further obliges the relatives to report the death to their local funeral authority within two days. The funeral authority formally notifies relevant government agencies, including the Central Office for Personal Registration (CPR Registeret) and the Probate Court (Skifteretten), which supervises the 
processes that transfer legal title of property from the deceased's estate to the beneficiaries. Skifteretten immediately seizes the deceased's assets, with the purpose of meeting liabilities, and transfers the net worth to the beneficiaries according to the sharing rule established by the inheritance law and possible wills. The inheritance law further requires that the transfer of the deceased's estate be finalized within 12 months after the death date. The net worth of the estate is subject to a $15 \%$ estate tax for immediate relatives (Group 1) if the estate's net wealth exceeds a threshold of 191,000 DKR (25,638 EUR) in 1998. This threshold is inflated by a price index in following years. The estate tax is supplemented with an additional $25 \%$ inheritance tax for people who are not immediate family members of the deceased (i.e., Group 2 or 3 relatives, which we omit in this study). The estate tax is levied on the estate's total net assets, irrespective of the underlying assets. Unrealized capital gains incurred by the deceased from financial or real estate investments are not directly taxed, thus beneficiaries have no tax incentives to either keep or liquidate specific assets.

\subsection{Data sources}

We construct a dataset with 17,191 individual beneficiaries who unexpectedly inherited wealth as a result of the sudden death of their legal parents (10,344 household terminations). Our dataset contains economic, financial, and personal information about the individuals, as well as their deceased parents, from relevant official registers. Demographic, income, and wealth data are comparable to the data used by Calvet, Campbell, and Sodini $(2007,2009)$ from Sweden. The information on the official medical causes of death in our data, however, provides a novel source to identify wealth shocks. The dataset was constructed based on four different sources made available from Statistics Denmark, as explained below. ${ }^{7}$

\footnotetext{
7 Collectively, these data are available for researchers through Statistics Denmark, but one has to obtain permission to access individual, confidential data. Access is granted to researchers associated with academic
} 
A. Individual and family data are from the official Danish Civil Registration System. These records include the personal identification number (CPR), name, gender, date of birth, names, and CPR numbers of nuclear family members (parents, siblings, and children) and individuals' marital history (number of marriages, divorces, and widowhoods). In addition to providing control variables, such as age, gender, and marital status, these data enable us to identify all individuals' legal parents. The sample contains the entire Danish population and provides unique identification across individuals and households over time.

B. Income and wealth information is from the official records at the Danish Tax Authorities (SKAT). This dataset contains personal income and wealth information by CPR numbers on the Danish population. SKAT receives this information directly from the relevant sources; financial institutions supply information to SKAT on their customers' deposits, on interest paid or received, and on security investments and dividends. Employers similarly supply statements of wages paid to their employees. Through Statistics Denmark, we obtain access to personal income and wealth data from 1990 to 2006 . However, prior to 1997, investments in stocks were self-reported. In 1997 a tax reform changed the source of the financial wealth data from self-reporting to mandatory reporting directly from financial intermediaries. As a result, we have reliable data for the entire Danish population on individuals' stock holdings from 1997 to 2006. We index all income and wealth variables to year 2000 DKR throughout the analysis.

C. Causes of deaths are from The Danish Cause-of-Death Register at the Danish National Board of Health (Sundhedsstyrelsen). In this dataset, the cause of death is classified according to international guidelines specified by the World Health Organization's (WHO) International Classification of Deceases (ICD-10) system. ${ }^{8}$ The sources of these

institutions, but data cannot, due to its sensitive nature, be exported from the closed server environment provided by Statistics Denmark.

8 WHO's International Classification of Deceases, ICD-10, is the latest in a series which has its origin in the $1850 \mathrm{~s}$. The first edition, known as the International List of Causes of Death, was 
data are the official death certificates that are issued immediately after the death of every deceased Danish citizen. The death certificate details the cause of death based on postmortem examination reports, information on social and psychiatric history provided by family members and associates, and other corroborating information, such as suicide notes. In Denmark, both the death certificate and the post-mortem examination report are completed by a doctor and, therefore, convey a medically qualified opinion on the cause of death. Sundhedsstyrelsen compiles these data for statistical purposes and makes it available for medical and social science research through Statistics Denmark. We obtain the cause of death from all Danish citizens who passed away between 1998 and 2003. We use this dataset to identify a sample of individuals who died suddenly and unexpectedly.

D. Educational records are from the Danish Ministry of Education. All completed (formal and informal) education levels are registered on a yearly basis and made available through Statistics Denmark. We use these data to measure an individual's education level and identify individuals who have either formal (university) education in economics or finance, or, alternatively, have obtained knowledge about finance through apprenticeships in the financial industry.

\subsection{Data construction}

To identify individuals whose parents have died, we link the data on cause of death to the family data by $C P R$ numbers. Thus, the starting point of our analysis is deceased parents who cause a termination of their household. Terminations of households occur whenever the last living parent dies, or when both parents die within the same calendar year. In total we identify 71,081 terminations of households between 1998 and 2003 . Panel A in Table 1 shows the distribution across time. From this sample we identify the cause of death for the purpose of selecting a sample of household terminations resulting

adopted by the International Statistics Institute in 1893. WHO took over the responsibility of ICD at its creation in 1948, and the system is currently used for mortality and morbidity statistics by all Member States. The current ICD-10 standard came into use by Member States in 1994. 
from sudden and unexpected death. Panel B details the cause of death based on WHO's ICD-10 codes.

To identify sudden and unexpected deaths, we rely on a medical literature that defines sudden death as unexpected death that occurs instantaneously or within a few hours of an abrupt change in the person's previous clinical state. To identify the relevant ICD-10 codes, we both search the medical literature and inspect WHO's detailed classification system. ${ }^{9}$ The medical literature distinguishes between natural and unnatural deaths, where natural deaths are due to diseases and declining health and unnatural deaths are due to accidents and violence [see, for an example, Li, Precht, Mortensen, and Olsen,(2003)]. Among natural deaths, acute myocardial infarction (ICD-10: I22-I23), cardiac arrest (I46), congestive heart failure (I50), stroke (I60-I69) and sudden deaths by unknown causes (R95-R97) are considered sudden deaths. Among unnatural deaths, traffic accidents (V00V89) and deaths caused by other accidents and violence (V90-V99, X00-X59, and X86X90) are sudden and unexpected to the relatives. The latter category excludes suicide or violence by subjects related to the deceased. Panel B tabulates the number of deaths for subcategories of sudden deaths, whereas Panel C shows the total number per year. In total we identify 10,344 terminations of households resulting from sudden deaths between 1998 and 2003.

The final step in our sample selection is to link the deceased to their beneficiaries. On average, each terminated household had 1.66 beneficiaries (i.e., children aged 18+), expanding our sample size to 17,191 individuals who experience a wealth windfall as a result of the sudden deaths of their parents. In Panel D, we show the subsample of household terminations where both parents die suddenly within the same year. In total, we find 801 such cases, corresponding to 1,362 beneficiaries. We use this subsample as a robustness check because, everything else being equal, inheritance from this group is more surprising. Once the final step has been carried out, all of the individual

${ }^{9}$ See WHO's webpage at www.who.int/classifications/icd/en. 
characteristics of the beneficiaries can be identified by linking beneficiaries' information through the $C P R$ number.

Table 2 presents summary statistics of our final sample. As the main focus is to identify entry and participation constraints in the stock market, we split our sample into pre-inheritance participants and non-participants. For each beneficiary, we observe stock market participation, income, wealth, age, gender, education, and marital status for the year prior to parents' sudden death. Income after-tax and wealth are indexed to constant year 2000 DKR. On average, $21.7 \%$ of the beneficiaries participated in the stock market. Among participants, $33.6 \%$ of their financial wealth was invested in stocks. As is consistent with prior literature, Table 2 shows that in the cross-section stock market, participants have significantly higher income and wealth, are older, and are better educated than non-participants. Prior literature interprets these cross-sectional differences in individual characteristics of participants and non-participants as evidence of fixed entry and participation costs. Table 2 also shows that men and married individuals are more likely to participate in the stock market.

\subsection{Empirical strategy}

We formally test whether fixed costs explain non-participation in the stock market by identifying the effect of windfall wealth on participation around the time of the parent's sudden death. If fixed costs deter participation, we expect individuals to participate if the windfall is large enough to incur the fixed costs. As our main purpose is to understand the impact of fixed costs on entry and exit decisions, we split the sample into individuals that are either non-participants or participants before the event, respectively. We examine the entry decision for non-participants and the ongoing participation decision for participants in separate analyses, to isolate the effect of fixed entry costs on participation from reoccurring, ongoing participation costs. 
Our comparison of individuals' participation choice before and after receiving windfall wealth is attractive because it effectively controls for time-invariant individual characteristics (e.g., ability and education) that are likely to impact the decision to participate in the stock market. One concern with this approach is that individuals might choose to participate because their income and wealth over time allow them to, or because the cost of participation is decreasing over time. We therefore compare the treatment group to a control group of individuals with the same characteristics who do not receive windfall wealth.

The control group is a matched sample of individuals from the Danish population, having the same age, gender, and education level, and from the same rank (vigintile) of both the income and wealth distribution as the treated individual. Moreover, we condition the matched sample on the participation decision such that we compare the reaction for pre-inheritance non-participants (participants) to a control group of non-participants (participants). For each control group, we calculate the average stock market participation, which represents the expected change in participation for the non-treated conditional on individual characteristics. This approach provides us with a difference-in-differences estimate of the effect of windfall wealth on stock market participation.

All empirical estimates in this study are based on a difference-in-differences specification. The difference-in-differences approach effectively controls for timeinvariant heterogeneity. This control is important, as inherited wealth might correlate with individual characteristics (e.g., ability) related to social heritage. We also include control variables that focus on changes in individual characteristics that are likely to affect income, wealth, and ultimately stock market participation; we refer to these variables as preference shifters. ${ }^{10}$ Our preference shifters include indicator variables if the individual marries, divorces, has children, or changes educational status during the event window.

\footnotetext{
${ }^{10}$ This strategy follows directly from Brunnemeier and Nagel (2008) and captures investment reallocations that result from major changes in household status.
} 
We also include year fixed effects to control for individual-invariant time effects. Finally, we note that each observation consists only of one observation before and after the event, thus keeping concerns about serial correlation to a minimum [Bertrand, Duflo, and Mullainathan (2004)].

\section{Empirical Results}

\subsection{Entry and participation costs in the stock market}

Table 3 provides the first insights into the effect of inherited wealth on stock market participation by comparing participation before and after the unanticipated inheritance. Panel A focuses on the entry decision for pre-inheritance non-participants, whereas Panel B reports results for the continued participation decision for pre-inheritance participants.

Panel A shows that, for the subsample of pre-inheritance non-participating individuals, $13.1 \%$ chose to enter the stock market three years after receiving windfall wealth. This increase is significantly different from zero at the $1 \%$ level. The expected participation absent any windfall is 8.8 percentage points, as shown for the matched sample of non-participating individuals with the same age, gender, income, and level of wealth. The difference in differences of 4.3 percentage points is significant at the $1 \%$ level and implies that, compared with the entry rate of the control group, windfall wealth induces an additional $4.3 \%$ of non-participating individuals to enter the stock market. Although this increase is consistent with fixed entry costs, the estimated effect of less than 5 percentage points is surprisingly low given the emphasis on fixed entry costs in prior literature.

In Panel B we focus on the continued participation decision for the subsample of preinheritance participants. If individuals face ongoing participation costs in the stock market, we expect individuals who received windfall wealth to stay in the stock market, compared with the participation rate of the control group. After receiving windfall wealth, $85.7 \%$ of the individuals still chose to participate in the stock market, compared to $85.5 \%$ 
for the matched sample. The difference in differences of 0.2 percentage points is insignificant. Thus, receiving unexpected and sudden inheritance appears to have little effect on continued participation, and the same fraction of beneficiaries and nonbeneficiaries exits the stock market following a sudden inheritance event. This evidence points to entry costs as the main participation costs.

One obvious explanation for these relatively modest reactions to unanticipated inheritance is that the windfall might be too small to offset the fixed costs. Table 4, therefore, shows the difference-in-differences estimate for deciles of inherited wealth. Table 4 sorts the inheritance sample according to the size of windfall wealth. For the bottom $20 \%$ of the individuals whose parent suddenly dies, the net worth of these estates is equal to zero. Thus, for this group we expect a marginal response in stock market participation. For the top decile of the distribution, the mean inheritance is 1.162 million DKR (156,000 EUR). For this group we expect to see significant changes if fixed participation costs matter.

Consistent with this argument, Table 4 reveals that the effect on participation increases with inherited wealth. For low levels of windfall wealth, the response is almost identical to the matched sample, compared to 22.7 percentage points in the top decile. We observe a small negative response in the lowest deciles, contrary to the intuition of inheriting wealth. For low deciles of windfall wealth, the average net wealth of the estate is quite small and perhaps not large enough to cover the cost of the funeral or costs related to the termination of the household (lawyers, movers, cleaners, etc.). ${ }^{11}$ Still the most striking result in Table 4 is that, even for the top decile of inherited wealth, only $35 \%$ of the non-participants respond to windfall wealth by entering the stock market. Thus, almost two-thirds of these individuals remain non-participants despite receiving

11 The average funeral cost is, according to the Danish Ministry of Finance (1998), 8,400 DKR if the body is cremated and 9,300 DKR if it is buried (in $2000 \mathrm{DKR}$ ). Pre-arranged (and pre-paid) funerals are rather uncommon in Denmark, as they make up less than $10 \%$ of all funerals. This fraction is expected to be lower in our sample of sudden deaths, and, as a result, beneficiaries will in general arrange the funeral. The funeral costs probably mean that beneficiaries in the low-wealth deciles experience a small negative wealth shock and therefore are less likely to invest in stocks than are those in the matched sample. 
significant windfall wealth that averages 1.2 million DKR. Considering the size of the average windfall within this group, this result appears inconsistent with the conclusion that fixed costs offer the main explanation for non-participation.

Panel B shows difference in differences for continued participants across deciles of windfall wealth. Continued participation increases with inherited wealth, although the effects are quite modest. The difference in differences are only significant for the two top deciles; even among these individuals, who receive large windfalls averaging 2.6 million DKR, around 5\% still choose to sell out. Thus, in keeping with the estimates in Table 3, we find little evidence to suggest that ongoing participation costs are important in explaining stock market participation outcomes.

Although the difference-in-differences estimates successfully control for timeinvariant individual heterogeneity (e.g., ability and social heritage) that might affect stock market participation, individuals' household status (e.g., marital status) might change over time. In Table 5 we therefore run cross-sectional regressions of the difference in differences on inherited wealth while controlling for preference shifters and year fixedeffects.

In Column 1 of Table 5, we regress the difference in differences on the amount of inherited wealth and find that the probability of entering the stock market (relative to the matched sample) is 12.3 percentage points larger for each million DKR (134,000 EUR) of inherited wealth. In Column 2 we include a squared term of inherited wealth, capturing the implication of a fixed-cost argument that the marginal effect of wealth on stock market participation is decreasing. Consistent with this argument, we find that the square term is negative and significant at the $1 \%$ level. The marginal effect of the first million DKR of inherited wealth implies a 21.2 percentage point larger probability of participation, compared to a marginal effect of 18.4 percentage points for the following million. Although, our difference-in-differences estimates provide evidence of fixed entry costs in the stock market, the estimated effects are relatively small: even substantial 
windfall wealth of one million DKR (134,000 EUR) only increases participation rates by around 21.2 percentage points. ${ }^{12}$

Columns 3 and 4 focus on continued participation. Column 3 shows that windfall wealth of one million DKR (134,000 EUR) only implies a 0.4 percentage point larger probability that the beneficiary will stay in the stock market. Although the marginal effect of inherited wealth increases when we include a squared term in Column 4, the effects are still small. Even large windfalls can only explain a trivial fraction of the variation in the ongoing participation decisions. Thus, although the evidence is supportive of fixed ongoing participation costs, it appears to be a second order effect.

\subsection{More evidence on entry and participation costs}

In this section we exploit variation in characteristics of beneficiaries to understand how age, education, and financial literacy affect fixed entry and ongoing participation costs.

In Column 1 of Table 6 we show how age matters for stock market participation. If one-time entry costs are important, we expect older individuals to respond less than younger beneficiaries to windfalls, because they have a shorter time horizon in which to harvest the benefits of the sunk cost. Alternatively, we expect age to have a negligible effect if the fixed costs represent only ongoing participation costs. To investigate this effect, we interact age with inherited wealth. In Column 1 we find no direct effect of age, but a significant effect on participation when age is interacted with the size of windfall wealth. Although the interaction term at first glance seems small, the marginal effect of inheriting one million DKR is 41.8 percentage points for a 20 -year-old individual, as compared to only 9.8 percentage points for a 60 -year-old. We interpret this as evidence of one-time costs related to entering the stock market. This finding also bolsters our main

\footnotetext{
${ }^{12}$ In comparison, the marginal effect on participation of one million DKR in wealth is $6 \%$ in the cross-section, and only $1 \%$ when using the panel dimension. Thus, compared to the results from the natural experiment, cross-sectional and panel data estimates are significantly biased.
} 
argument that sudden bequests do provide an exogenous shock to wealth because windfalls are more unanticipated for young individuals. In Column 2 of Table 6, we examine how education matters for stock market participation. If education lowers the participation costs, as is argued in prior literature, we expect to find a direct effect of education on participation, but a smaller per-dollar effect of inheritance when controlling for the level. Simply put, individuals with higher levels of education should react more positively to even small levels of windfall wealth than do individuals with lower levels of education. Moreover, this difference in participation outcomes related to educational levels should decline as inherited wealth increases.

We find that length of education has a direct, statistically significant effect on participation and that inheritance has a smaller per-dollar effect for highly educated individuals - although the effects are very modest. Each additional year of education raises the participation rate by 0.52 percentage points, whereas one million DKR of inherited wealth decreases this effect by 0.59 percentage points per year of schooling. Evaluating the joint effect, one has to add the direct effect of inherited wealth with the interacting effect of education: consequently, a high school drop-out with 10 years of schooling is 7.6 percentage points more likely to enter the stock market when he inherits 100,000 DKR. When inherited wealth increases to one million DKR, the marginal effect on participation increases to 27.4 percentage points. In comparison, an individual with a university degree (17 years of schooling) will be 10.8 and 26.9 percentage points more likely to participate when inheriting 100,000 and one million DKR, respectively. Thus, for low levels of windfalls, the highly educated respond more positively to inherited wealth, whereas the difference diminishes as inherited wealth increases. This finding bolsters the interpretation given in much of the prior literature, that individuals with longer periods of education have lower fixed objective costs.

A potential explanation for the low explanatory power of fixed costs in the natural experiment is that some individuals might be unaware of the existence of stocks as an 
asset class. For instance, Guiso and Jappelli (2005) report that over 35\% of Italian households in the mid- and late 1990s apparently were unaware of stocks. On the other hand, Campbell (2006) argues that although this might explain non-participation in some countries, this proportion is likely to be much smaller in countries with more developed financial markets. To ascertain that our results are not driven by unawareness, we examine whether the reactions to windfall wealth are different for individuals who are financially literate.

In Columns 3 and 4 of Table 6, we therefore define an indicator for financially literate individuals who either hold a university degree in economics, finance, or related disciplines, or have obtained informal education during an apprenticeship in the financial industry. Consistent with the general effect of education, we find that financially literate individuals are 9.7 percentage points more likely to enter the stock market. This effect appears to decline with inherited wealth, although the few observations make it hard to estimate the coefficient with precision. Financially literate individuals who inherit one million DKR have a 7.0 percentage point higher probability of entering the stock market. This effect remains significant even when controlling for the direct effect of education (Column 4). In summary, unawareness does not play a large role in explaining nonparticipation in our setting.

\subsection{The effect of investment inertia and procrastination}

Two plausible explanations for the modest response to windfall wealth are investment inertia and procrastination. We examine investment inertia and procrastination through two separate approaches: first, the effect of inertia is addressed by extending the horizon of the evaluation period. Second, procrastination is examined by analyzing whether the composition of the inherited estate's portfolio matters for beneficiaries' portfolio choice.

If individuals are slow to change their investment decisions, inertia will negatively bias the estimated effect of inherited wealth on stock market entry. In related findings, prior 
literature has documented the presence of inertia in asset allocation. Participants in retirement savings plans, for instance, rarely alter the allocations of their contributions or rebalance their portfolios [Madrian and Shea (2001), Agnew, Balduzzi, and Sundén (2003), Ameriks and Zeldes (2004), Choi, Laibson, Madrian, and Metrick (2002, 2004)]. Consistent with inertia, capital gains and losses are also found to generate little portfolio rebalancing in U.S. survey data studied by Brunnermeier and Nagel (2008).

In Table 7 we therefore look at the effect outside the current event windows from year -1 to +3 . In particular, we examine when inherited wealth has predictive power in explaining the stock market entry decision (Columns 1 to 3 ) and the continued participation decision (Columns 4 to 6 ) in alternative windows, covering the initial period from -1 to +1 and subsequent periods from year +1 to +3 and year +3 to +5 . For the entry (ongoing participation) decision, our sample includes only non-participants (participants) at the beginning of each event window. Thus, the marginal effects identify the effect of delaying the investment decision on account of inertia.

We find some evidence of investment inertia as inherited wealth is positively related to participation decisions in subsequent periods. Individuals who inherit one million DKR are 8.9 percentage points more likely to decide to enter the stock market from year +1 to +3 . However, in the subsequent event window, from year +3 to +5 , we only find insignificant effects of inherited wealth on participation. Thus, although some individuals do delay the investment decision on account of inertia, inertia cannot explain the surprisingly low effect of fixed entry costs on stock market participation in our main window from -1 to +3 .

In Columns 5 and 6 we find a limited and only marginally significant effect of inherited wealth on ongoing participation decisions in subsequent periods. This is consistent with our general finding that ongoing participation costs seem to be a second order effect in explaining why individuals leave the stock market. 
The second aspect of investment inertia is related to procrastination. Prior literature demonstrates that procrastination plays an important role in individuals' savings and investment decisions. For instance, Madrian and Shea (2001) show that $401(\mathrm{k})$ enrollment rates are significantly higher under automatic enrollment of employees. If the participation decision in our setting is affected by procrastination, inheriting an estate holding stocks should increase the probability of participation, simply because it changes the active decision from deciding to enter the stock market to choosing to exit the market. The institutional setting is helpful in identifying the effect of procrastination because potential capital gains not are subject to taxation in the event of inheritance. Thus, inheritance tax is solely determined by net wealth, and unaffected by the composition of wealth.

In Column 1 of Table 8, we therefore include an indicator variable taking the value 1 if the estate held stocks. Out of the 13,463 non-participants in the sample, 3,208 beneficiaries $(23.8 \%)$ inherited from an estate that held stocks. The effect of inheriting stock on participation rates is both economically and statistically significant. Inheritance of stocks increases the participation rate by 12.7 percentage points. However, this effect might capture the factor that wealthier estates are more likely to hold stocks. In Column 2, we therefore split inherited wealth into two separate covariates: inherited wealth excluding stocks, and value of inherited stocks. Inherited wealth excluding stocks has almost the same effect on participation as that tabulated in Table 5: one million DKR in inheritance from other sources than stocks imply an 18.0 percentage point larger probability of participation. Now, compare this to the estimated coefficient on the value of inherited stocks. Inheriting one million DKR worth of stocks increases the probability of stock market participation by 43.7 percentage points. Thus, the effect on participation of inheriting stocks is significantly larger than that of inheriting cash in both economic and statistical terms.

In Column 3 we expand the specification by including the indicator variable for inheriting stocks. Again, the indicator variable for inheritance of stocks is positive and 
highly significant. If the estate held stocks, the probability of participation increases by 12.2 percentage points. The difference between the first inherited million DKR worth of stocks compared to inheriting cash is only 9.3 percentage points. Still, despite the marginal effect of procrastination, fixed costs cannot explain why the majority of individuals shy away from stocks.

The evidence in Table 8 is also helpful in addressing whether non-participation is caused by borrowing constraints, as suggested by Constantinides, Donaldson, and Mehra (2002), and Davis, Kubler, and Willen (2006). In the presence of credit constraints, a bequest increases wealth and reduces this constraint. As such, our identification strategy does not directly identify whether non-participation initially is caused by borrowing constraints, however given that individuals who inherit large positions of stocks sell out, borrowing constraints are unlikely to explain the results.

\subsection{Interpretation}

We use exogenous variation in an individual's wealth to identify the relative importance of fixed entry and participation cost in understanding why people shy away from the stock market. Although we generally find evidence consistent with the existence of such costs, our results demonstrate that these costs have relatively modest power in explaining limited participation. Three years after receiving windfall wealth, only $13.1 \%$ of all beneficiaries have invested in stocks. Among individuals receiving large inheritance of more than one million DKR, around one-third enters the stock market, while two-thirds remain non-participants.

Our ability to infer that non-participation for the majority of households cannot be explained by fixed costs hinges on the assumption that individuals actually keep some of the windfall as financial wealth. If the entire inheritance is instantly consumed, we might learn little about investment behavior and more about individual preferences to consume inheritance. In Table 9 we report the holdings of financial wealth in cash and bonds both 
before and after receiving inheritance for individuals who remain non-participants. In addition, we report the distribution of the change in financial wealth. Panel A reports financial wealth for all individuals, and Panel B reports for individuals receiving more than one million DKR in inheritance. The average holding of financial assets almost doubles for individuals who receive windfall wealth. An average beneficiary increases his/her holdings of financial assets by 31,800 DKR (4,300 EUR). More importantly, for individuals who receive large windfalls of more than one million DKR, the financial assets increase by 207,600 DKR (27,900 Euro), respectively. Most of this increase comes from bank accounts that often carry the name of both the beneficiary and his/her spouse. Thus, individual holdings will mechanically underestimate the change in financial wealth due to inheritance, because deposits in bank accounts with two account holders only count half at the individual level. In Panel B we therefore aggregate to the household level. The financial wealth increases on average by 58,700 DKR (7,900 Euro) to 125,800 DKR (16,900 Euro). For households receiving large windfalls of more than one million DKR, financial wealth increases by 364,900 DKR (49,000 Euro) to 512,000 DKR (68,700 Euro). Finally, Table 9 shows the distribution of the change in financial wealth. Around two-thirds of the individuals receiving windfall wealth of more than one million DKR, increase their financial wealth by more than $100 \%$. Thus, the individuals who receive large windfalls and remain non-participants have substantial financial wealth.

The fixed cost theory calculates a dollar value for the likely benefit of participation given financial wealth, the fraction of financial wealth in stocks conditional on entry, and the (certainty equivalent) expected excess return on the stock market. If those individuals who remain non-participants invest the same fraction of their financial wealth in stocks as do participants (33.6\%), then the potential yearly benefit from participation for individuals receiving large windfalls is equal to $8,600 \mathrm{DKR}$ (1,150 Euros) per year, assuming a 5\% 
certainty equivalent excess return on stocks (after tax). ${ }^{13}$ To be able to explain nonparticipation by means of ongoing participation costs, these costs have to exceed the yearly benefit from participation. To be able to explain non-participation by fixed entry costs, the entry cost has to exceed the present value of the yearly benefits of participation (which is equal to the annuity value of the estimated yearly participation benefit). Our analysis shows little evidence of ongoing participation costs, whereas fixed entry costs have some explanatory power in explaining non-participation. Given the large present value of the potential benefit from participation, however, fixed entry costs are unlikely to explain why many households who receive large windfalls choose not to participate. ${ }^{14}$ Collectively, these findings show that although fixed entry costs can account for around one-third of non-participants, a majority of individuals seem to be constrained by other factors.

\section{Alternative Specifications and Robustness Checks}

\subsection{Focusing on accidents}

One concern with the prior analysis it that although we identify deaths that appear to be sudden and unexpected to a family outsider, these might be somewhat expected by the deceased and their beneficiaries, as death is inevitable. To address this concern, Columns 1 and 6 in Table 10 show the results from the subsample of deaths caused by accidents. The results are very similar to the results reported in Table 5. For the entry decision, the marginal effect of one million DKR of windfall wealth has a 23.0 percentage point higher probability of holding stocks after three years. The marginal effect of one million DKR of inherited wealth on continued participation is 5.2 percentage points. Thus, by focusing

13 The benefit from participation is calculated as financial wealth $*$ portfolio share in stocks $*$ certainty equivalent excess return on stocks $=512.000 * 0.336 * 0.05=8,600$ DKR. In comparison, Vissing-Jørgensen (2002) assumes a 4\% certainty equivalent for the U.S. Capital gains are not subject to taxation during the sample period for investors with small stock investments in Denmark, whereas U.S. investors pay $20 \%$ tax.

${ }^{14}$ To be conservative, we ignore the impact of paying off mortgage, which in Denmark is backed by bonds. Paying off mortgage is, thus, equivalent to increasing financial wealth invested in bonds. As a result the estimated benefit from participation is conservative in the above calculation. 
on accidents that, by definition, are unpredictable, we confirm the results from our analysis based on a medical definition of sudden deaths. This finding also bolsters our primary argument — that sudden bequests do provide an exogenous shock to wealth.

\subsection{Focusing on cases in which both parents died within a year}

Our results might also be affected by our reliance on household terminations, which tend to be dominated by deceased widows. Given that the beneficiaries in these cases have already lost one parent, inheritance might be expected, in particular for older individuals, even if the cause of death is medically defined as sudden. To address this possibility, we identify the subsample of household terminations in which both parents died suddenly within a given year. In such cases, inheritance is more likely to be unanticipated. Columns 2 and 7 of Table $\mathrm{X}$ show the results for pre-inheritance nonparticipants and participants, respectively. For non-participants, our results are consistent with the prior analysis. One million DKR of inheritance has a 22.0 percentage point effect on participation, which is lower than the effect estimated in Column 2 of Table 5. For pre-inheritance participants, inherited wealth is also positive.

\subsection{Focusing on a sample within which sibling rivalry is absent}

Our results on investment inertia might also be explained by potential sibling rivalry and infighting over the estate. Potential conflicts among siblings may cause estates with many beneficiaries to take a longer time to liquidate, subsequently delaying the actual transfer of inherited wealth. In Columns 3 and 8 of Table 10, we therefore focus solely on estates with a single beneficiary (i.e., a lone child), within which such conflicts are absent. Again, we obtain results consistent with our main analysis.

\subsection{Aggregation to household decisions}


All of our results focus on beneficiaries' individual investment decisions. One valid concern is how much individual behavior differs from household behavior, and how assets are reallocated within the family. In unreported regressions, we have aggregated the analysis to the household level without detecting any meaningful differences in the results. In the aggregation, we only consider households with stable characteristics during the event window. ${ }^{15}$ Thus, if the household experiences death or divorce, which will change the composition of the household, we exclude the observation from the sample.

In Columns 4 and 9, we report the general effect at the household level of inherited wealth on the entry and exit decisions, respectively. The marginal effect of windfall wealth on participation is 21.6 percentage points, which is coherent with our prior findings. Thus, our main result, suggesting that fixed participation costs explain little of the variation in participation decisions, is not an artifact of carrying out the analysis at the individual level.

\subsection{Matching on parental age}

Another concern relates to whether inheritance is anticipated. Although we restrict the sample to sudden deaths, individuals might know their parent's exact wealth and might be able to borrow against expected inheritance. To control for this possibility, we include a match on the basis of parental age along with existing match characteristics. By matching on parental age, we control for differences in behavior related to anticipated bequests. Parental age is the minimum of the age of living parents. When we match on parental age, 13 percentage points of treated non-participants—in contrast to 8.7 percentage points of those in the control group-enter the stock market after three years. This gives a difference in differences of 4.4 percentage points, which is significant at the $1 \%$ level. In comparison, we find difference in differences of 4.3 percentage points in Table 3 . In Column 5 and 10 of Table 10, we further regress inherited wealth on the difference in

\footnotetext{
${ }^{15}$ As a result of the focus on stable households, we do not include preference shifters in the analysis.
} 
differences while controlling for preferences shifters. We note that the marginal effects are similar to the main specification, which suggests that anticipated bequests cannot explain our results.

\section{Conclusions}

The results from the natural experiment reveal that some individuals face entry and ongoing participation costs in the stock market. Receiving a windfall of one million DKR raises the probability of entering the stock market by approximately 21 percentage points, still leaving out many as non-participants. Although the magnitude of this result is affected by investment inertia and procrastination, we still find that a majority of individuals do not respond to windfall wealth, even over long horizons. This holds even for highly educated individuals, as well as for economists and people employed in the financial industry with access to information and knowledge about the stock market. Moreover, non-participants keep substantial wealth in cash and bonds, thereby foregoing the benefits from stock market participation. Thus, although fixed entry and ongoing participation costs discourage some individuals from investing in the stock market, these factors are unlikely to explain why the majority of non-participants shy away from stocks. 


\section{References}

Agnew, Julie, Pierluigi Balduzzi, and Annika Sundén, 2003, "Portfolio Choice and Trading in a Large $401(\mathrm{k})$ plan," American Economic Review 93, 193-215.

American Academy of Pediatrics, Guidelines for Pediatricians: Sudden Cardiac Death (SDC), Issue 9, November 2002.

Ameriks, John, and Stephen Zeldes, 2004, "How do Household Portfolio Shares Vary with Age?," working paper, Columbia University.

Ang, Andrew, Gert Bakaert, and Jun Liu, 2005, "Why Stocks May Disappoint," Journal of Financial Economics 76, 471-508.

Arrow, Kenneth J., 1974, Essays in the Theory of Risk Bearing (North Holland, Amsterdam)

Barberis, Nicholas, Ming Huang, and Richard H. Thaler, 2006, "Individual Preferences, Monetary Gambles, and Stock Market Participation," American Economic Review 96, 1069-1090.

Bertaut, Carol C., 1998, "Stockholding Behavior of U.S. Households: Evidence from the 1983-1989 Survey of Consumer Finances," Review of Economics and Statistics 80, 26375.

Bertrand, Marianne, Esther Duflo, and Sendhil Mullainathan, 2004, "How Much Should We Trust Difference in Difference Estimates?," Journal of Quarterly Economics 119 (1), 249-275.

Biais, Bruno, Peter Bossaerts, and Chester Spatt, 2004, "Equilibrium Asset Pricing under Heterogeneous Information," working paper, University of Toulouse.

Blume, Marshall, and Irwin Friend, 1974, "The Asset Structure of Individual Portfolios and Some Implications for Utility Functions," Journal of Finance 30, 585-603.

Blume, Marshall, and Irwin Friend, 1978, The changing role of the individual investor (John Wiley, New York, NY).

Brunnermeier, Marcus K., and Stefan Nagel, 2008, "Do Wealth Fluctuations Generate Time-varying Risk Aversion? Evidence from Individuals' Asset Allocation," American Economic Review 98, 713-736.

Calvet, Laurent, John Y. Campbell, and Paolo Sodini, 2007, "Down or Out: Assessing the Welfare Costs of Household Investment Mistakes," Journal of Political Economy 115, 707-747.

Calvet, Laurent, John Y. Campbell, and Paolo Sodini, 2009, "Fight or Flight? Portfolio Rebalancing by Individual Investors," forthcoming in Quarterly Journal of Economics.

Campbell, John Y., 2006, “Household Finance,” Journal of Finance 61, 1553-1604.

Choi, James J., David Laibson, Brigitte C. Madrian, and Andrew Metrick, 2002, "Defined Contribution Pensions: Plan Rules, Participant Decisions, and the Path of Least Resistance," in James Poterba, ed.: Tax Policy and the Economy (MIT Press) 16, 67113.

Choi, James J., David Laibson, Birgitte C. Madrian, and Andrew Metrick, 2004, "For Better or for Worse: Default Effects and 401k Savings Behavior," in David Wise, ed.: Perspectives in the Economics of Aging (University of Chicago Press), 81-126.

Christelis, Dimitris, Tullio Jappelli, and Mario Padula, 2009, "Cognitive Abilities and Portfolio Choice," forthcoming in European Economic Review. 
Christiansen, Charotte, Juanna S. Joensen, and Jesper Rangvid, 2008, “Are Economists More Likely to Hold Stocks?," Review of Finance 12, 465-496.

Cocco, Joao F., Francisco J. Gomes, and Pascal J. Maenhout, 2005, "Consumption and Portfolio Choice over the Life Cycle," Review of Financial Studies 18, 491-533.

Constantinides, George M., Donaldson, John B. and Rajnish Mehra, 2002, "Junior Can't Borrow: A New Perspective on the Equity Premium Puzzle," Quarterly Journal of Economics, 117, 269-296.

Danish Ministry of Finance, 1998, "Vilkår for dødsboer, arvinger og efterlevende," Report, Copenhagen, Denmark.

Davis, Steven J., Kubler, Felix, and Paul Willen, 2006. "Borrowing Costs and the Demand for Equity over the Life Cycle," Review of Economics and Statistics 88, 348-362.

Dimmock, Stephen G., 2005, "Loss-aversion and Household Portfolio Choice," working paper, Michigan State University.

Dominitz, Jeff, and Charles Manski, 2005, "Measuring and Interpreting Explanations of Equity Returns," working paper, Northwestern University.

Giannetti, Mariassunta, and Yrjö Koskinen, 2005, "Investor Protection and Demand for Equity," working paper, Stockholm School of Economics.

Grinblatt, Mark, Matti Keloharju, and Juhani Linnainmaa, 2009, "IQ and Stock Market Participation," working paper, University of Chicago.

Guiso, Luigi, Michael Haliassos, and Tullio Jappelli, 2001, Household Portfolios (MIT Press).

Guiso, Luigi, and Tullio Jappelli, 2005, "Awareness and Stock Market Participation," Review of Finance 9, 537-567.

Guiso, Luigi, Michael Haliassos, and Tullio Japelli, 2003, "Houshold Stockholding in Europe: Where Do We Stand and Where Do We Go?," Economic Policy 18, 123-170.

Guiso, Luigi, Paola Sapienza, and Luigi Zingales, 2008, "Trusting the Stock Market," Journal of Finance 63, 2557-2600.

Haliassos, Michael, and Carol Bertaut, 1995, Why Do so Few Hold Stocks? Economic Journal 105, 1110-1129.

Hong, Harrison, Jeffrey D. Kubik, and Jeremy Stein, 2004, "Social Interaction and Stockmarket Participation," Journal of Finance 59, 137-163.

King, Mervyn A., and Jonathan I. Leape, 1984, "Wealth and Portfolio Composition: Theory and Evidence," NBER Working paper.

Knox, Thomas A., 2003, "Foundations for Learning How to Invest when Returns are Uncertain," working paper, University of Chicago.

Li, Jiong, Dorthe H. Precht, Preben B. Mortensen, and Jørn Olsen, 2003, "Mortality in Parents after Death of a Child in Denmark: A Nationwide Follow-up Study," The Lancet 361, 363-367.

Madrian, Birgitte C., and Dennis F. Shea, 2001, "The Power of Suggestion: Inertia in 401(k) Participation and Savings Behavior," Quarterly Journal of Economics 116, 11491187.

Mankiw, N. Gregory, and Stephen P. Zeldes, 1991, "The Consumption of Stockholders and Nonstockholders," Journal of Financial Economics 29, 97-112.

Malmendier, Ulrike, and Stefan Nagel, 2009, "Depression Babies: Do Macroeconomic Experiences Affect Risk-taking?," working paper, Stanford University. 
Merton, Robert C., 1969, "Lifetime Portfolio Selection under Uncertainty: The Continuous-time Case," Review of Economics and Statistics 51, 247-257.

Merton, Robert C., 1971, "Optimum Consumption and Portfolio Rules in a Continuoustime Model," Journal of Economic Theory 3, 373-413.

Poterba, James M., and Andrew Samwick, 1999, "Taxation and Household Portfolio Composition: U.S. Evidence from the 1980s and 1990s," working Paper, NBER..

Puri, Manju, and David Robinson, 2005, "Optimism and Economic Choice," working paper, Duke University.

Ret og Råd, 2008, Analyse af den nye arvelov, Report, Copenhagen, Denmark.

Samuelson, Paul A.., 1969, "Lifetime Portfolio Selection by Dynamic Stochastic Programming," Review of Economics and Statistics 51, 239-246.

Vissing-Jørgensen, Annette 2002, "Towards an Explanation of Household Portfolio Choice Heterogeneity: Nonfinancial Income and Participation Cost Structures," working paper, NBER.

Vissing-Jørgensen, Annette, 2003, "Perspectives on Behavioral Finance: Does Irrationality Disappear with Wealth? Evidence from Expectations and Actions," in Mark Gertler and Kenneth Rogoff, eds.: NBER Macroeconomics Annual 2003 (MIT Press). 
Table 1. Causes of household terminations, 1998-2004

\begin{tabular}{|c|c|c|c|c|c|c|c|c|}
\hline & \multirow[t]{2}{*}{ IDC10 } & \multicolumn{6}{|c|}{ Year } & \multirow[t]{2}{*}{ Total } \\
\hline & & 1998 & 1999 & 2000 & 2001 & 2002 & 2003 & \\
\hline \multicolumn{9}{|l|}{ B. Deceased's cause of death } \\
\hline Natural & A00-R99 & 9,561 & 10,444 & 10,832 & 11,533 & 12,193 & 12,741 & 67,304 \\
\hline Acute myocardial infraction (a) & I22-I23 & 81 & 99 & 79 & 87 & 17 & 2 & 365 \\
\hline Cardiac arrest (b) & $\mathrm{I} 46$ & 60 & 73 & 87 & 78 & 106 & 123 & 527 \\
\hline Congestive heart failure (c) & $\mathrm{I} 50$ & 744 & 822 & 918 & 951 & 1044 & 1,109 & 5,588 \\
\hline Stroke (d) & I60-I69 & 228 & 270 & 213 & 276 & 336 & 346 & 1,669 \\
\hline Sudden death by unknown cause (e) & $\mathrm{R} 95-\mathrm{R} 97$ & 80 & 69 & 101 & 68 & 12 & 4 & 334 \\
\hline Unnatural deaths & V00-Z98 & 627 & 686 & 668 & 642 & 589 & 565 & 3,777 \\
\hline Traffic accidents (f) & V00-V89 & 44 & 55 & 59 & 49 & 45 & 51 & 303 \\
\hline Other accidents and violence $(\mathrm{g})$ & V90-V99 & 233 & 294 & 291 & 253 & 233 & 254 & 1,558 \\
\hline & $\mathrm{X} 00-\mathrm{X} 59$ & & & & & & & \\
\hline \multicolumn{2}{|c|}{ C. Sudden household terminations $(a+b+c+d+e+f+g)$} & 1,470 & 1,682 & 1,748 & 1,762 & 1,793 & 1,889 & 10,344 \\
\hline \multicolumn{2}{|c|}{ Average number of beneficiaries } & 1.58 & 1.60 & 1.65 & 1.70 & 1.70 & 1.73 & 1.66 \\
\hline \multicolumn{2}{|l|}{ Number of beneficiaries } & 2,296 & 2,697 & 2,884 & 3,016 & 3,050 & 3,248 & 17,191 \\
\hline \multicolumn{2}{|l|}{ Terminations with single beneficiaries } & 923 & 1,007 & 1,015 & 972 & 1,008 & 989 & 5,914 \\
\hline \multicolumn{2}{|l|}{ D. Both parents die within the year } & 100 & 152 & 150 & 117 & 140 & 142 & 801 \\
\hline \multicolumn{2}{|l|}{ Average number of beneficiaries } & 1.69 & 1.66 & 1.69 & 1.76 & 1.62 & 1.78 & 1.70 \\
\hline \multicolumn{2}{|l|}{ Number of beneficiaries } & 169 & 253 & 254 & 206 & 227 & 253 & 1,362 \\
\hline
\end{tabular}

Note: This table shows the cause of death for terminated households from 1998 to 2004. A household is terminated whenever the last member dies or, in the rare case, when a couple dies within the year. ICD-10 is the World Health Organization's International Classification of Deceases. Codes are: Natural (A00-R99) and unnatural deaths (V00Y98). Within both natural and unnatural deaths, Panel B shows the number of sudden deaths caused by: acute myocardial infraction (I22-I23), cardiac arrest (I46), congestive heart failure (I50), stroke (I60-69), sudden unexpected death by unknown cause (R95-R97), traffic accident (V01-V89), and other accidents and violence (V90-V99, X00-X59 \& X86-X90). Other accidents and violence do not include suicides or violence caused by relatives of the deceased. 
Table 2. Descriptive statistics: Characteristics of pre-inheritance stock market participants versus non-participants

\begin{tabular}{|c|c|c|c|c|}
\hline & \multirow[t]{2}{*}{ All } & \multicolumn{2}{|c|}{$\begin{array}{c}\text { Pre-inheritance } \\
\text { stock market participation }\end{array}$} & \multirow{2}{*}{$\begin{array}{l}\text { Difference } \\
\text { (I)-(II) }\end{array}$} \\
\hline & & $\begin{array}{l}\text { Yes } \\
\text { (I) }\end{array}$ & $\begin{array}{l}\text { No } \\
\text { (II) }\end{array}$ & \\
\hline \multicolumn{5}{|c|}{ A. Stockholdings, financial wealth, and income } \\
\hline Share of Stockholders & $\begin{array}{c}0.217 \\
(0.412)\end{array}$ & 1 & 0 & \\
\hline Portfolio share in stocks & $\begin{array}{c}0.134 \\
(0.238)\end{array}$ & $\begin{array}{c}0.336 \\
(0.141)\end{array}$ & 0 & \\
\hline Income after tax (1000s) & $\begin{array}{c}214.95 \\
(150.17)\end{array}$ & $\begin{array}{c}252.10 \\
(218.82)\end{array}$ & $\begin{array}{c}204.66 \\
(122.68)\end{array}$ & $47.44^{* * *}$ \\
\hline Wealth (1000s) & $\begin{array}{c}157.90 \\
(1137.29)\end{array}$ & $\begin{array}{c}498.13 \\
(2007.99)\end{array}$ & $\begin{array}{r}63.681 \\
(703.14)\end{array}$ & $434.45^{* * *}$ \\
\hline \multicolumn{5}{|c|}{ B. Individual characteristics } \\
\hline Age (years) & $\begin{array}{l}41.92 \\
(9.45)\end{array}$ & $\begin{array}{l}45.40 \\
(9.21)\end{array}$ & $\begin{array}{l}40.96 \\
(9.28)\end{array}$ & $4.44^{* * *}$ \\
\hline Gender ( $\%$ male $)$ & $\begin{array}{c}54.74 \\
(49.78)\end{array}$ & $\begin{array}{c}60.75 \\
(49.78)\end{array}$ & $\begin{array}{c}53.08 \\
(49.90)\end{array}$ & $7.67^{* * *}$ \\
\hline Education (years) & $\begin{array}{l}11.91 \\
(2.82)\end{array}$ & $\begin{array}{l}12.60 \\
(2.89)\end{array}$ & $\begin{array}{l}11.73 \\
(2.78)\end{array}$ & $0.84^{* * *}$ \\
\hline Married (\%) & $\begin{array}{c}52.29 \\
(49.94)\end{array}$ & $\begin{array}{c}60.62 \\
(48.87)\end{array}$ & $\begin{array}{l}49.99 \\
(50.00)\end{array}$ & $10.63^{* * *}$ \\
\hline Children in household (\%) & $\begin{array}{c}49.05 \\
(49.99)\end{array}$ & $\begin{array}{c}47.61 \\
(49.95)\end{array}$ & $\begin{array}{l}49.50 \\
(50.00)\end{array}$ & $-0.02^{* *}$ \\
\hline $\mathrm{N}$ & 17,191 & 3,728 & 13,463 & \\
\hline
\end{tabular}

Note: We report descriptive statistics: mean and standard deviation for all beneficiaries, beneficiaries that are pre-inheritance participants and non-participants, respectively. For each beneficiary we observe income after tax, wealth, age, gender, years of schooling, marital status and whether there are children in the household. For each set of descriptive statistics we also compute the difference in the average characteristics of pre-inheritance participants and non-participants and test whether these differences are significantly different from zero. All amounts are in thousand year 2000 DKR. Standard errors are in parentheses, and t-statistics are in square brackets. ${ }^{* * *}, * *$, and $*$ denote significance at the $1 \%, 5 \%$, and $10 \%$ levels, respectively. 
Table 3. Difference-in-differences estimation of the effect of unexpected inheritance on stock market participation

\begin{tabular}{lccc}
\hline & \multicolumn{2}{c}{ Sample } & Difference \\
\cline { 2 - 3 } & $\begin{array}{c}\text { Unexpected } \\
\text { inheritance } \\
(1)\end{array}$ & Matched & $(3)$ \\
\hline A. Entry & 0.000 & 0.000 & 0.000 \\
Before & 0.131 & 0.088 & $(0.000)$ \\
After & $0.131^{* * *}$ & $0.088^{* * *}$ & $0.043^{* * *}$ \\
Difference & $(0.003)$ & $(0.001)$ & $0.0033^{* * *}$ \\
& 13,463 & & $(0.003)$ \\
N & & & \\
B. Continued participation & & 1.000 & 0.000 \\
Before & 1.000 & 0.855 & $(0.000)$ \\
After & 0.857 & $-0.144^{* * *}$ & $(0.005)$ \\
Difference & $(0.003)$ & 0.002 \\
& $(0.006)$ & & $(0.005)$ \\
N & 3,728 & & \\
\hline
\end{tabular}

Note: Unexpected inheritance is our sample of individuals who suddenly inherit their parent's estate. The matched sample is a control group of individuals of the same age, gender, length of education, and rank (vigintile) of both income and wealth distribution. Panel A reports the entry decision for the subsample of pre-inheritance non-participants 1 year before and 3 years after the sudden death event, and differences in these measures around the event. Panel B presents before, after, and differences for continued participation decisions for the subsample of pre-inheritance participants. Standard errors are in parentheses. $* * *, * *$, and $*$ denote significance at the $1 \%, 5 \%$, and $10 \%$ levels, respectively. 
Table 4. Difference-in-differences estimation of the effect of unexpected inheritance on stock market participation by deciles of inherited wealth

\begin{tabular}{lccccc}
\hline $\begin{array}{l}\text { Inherited wealth } \\
\text { decile }\end{array}$ & $\begin{array}{c}\text { Mean inherited } \\
\text { wealth }(1000 \mathrm{~s})\end{array}$ & $\begin{array}{c}\text { Before } \\
(1)\end{array}$ & $\begin{array}{c}\text { After } \\
(2)\end{array}$ & $\begin{array}{c}\text { Difference } \\
(3)\end{array}$ & $\begin{array}{c}\text { Difference in } \\
\text { Differences }\end{array}$ \\
\hline & & & & & \\
A. Entry & & & & & \\
1 \& 2 & 0 & 0.000 & 0.060 & $0.060^{* * *}$ & $-0.009^{* *}$ \\
3 & 1.7 & 0.000 & 0.048 & $0.048^{* * *}$ & $-0.025^{* * *}$ \\
4 & 6.5 & 0.000 & 0.069 & $0.069^{* * *}$ & $-0.010^{*}$ \\
5 & 16.4 & 0.000 & 0.079 & $0.079^{* * *}$ & -0.003 \\
6 & 43.4 & 0.000 & 0.111 & $0.111^{* * *}$ & $0.022^{* * *}$ \\
7 & 102.2 & 0.000 & 0.125 & $0.125^{* * *}$ & $0.037^{* * *}$ \\
8 & 201.8 & 0.000 & 0.171 & $0.171^{* * *}$ & $0.074^{* * *}$ \\
9 & 372.8 & 0.000 & 0.238 & $0.238^{* * *}$ & $0.129^{* * *}$ \\
10 & $1,162.3$ & 0.000 & 0.350 & $0.350^{* * *}$ & $0.227^{* * *}$ \\
& & & & \\
B. Continued participation & & & & & \\
$1 \& 2$ & 2.5 & 1.000 & 0.787 & $-0.213^{* * *}$ & $-0.041^{* * *}$ \\
3 & 18.0 & 1.000 & 0.831 & $-0.170^{* * *}$ & -0.010 \\
4 & 49.2 & 1.000 & 0.861 & $-0.139^{* * *}$ & 0.012 \\
5 & 103.8 & 1.000 & 0.839 & $-0.161^{* * *}$ & -0.004 \\
6 & 187.4 & 1.000 & 0.863 & $-0.137^{* * *}$ & 0.011 \\
7 & 295.1 & 1.000 & 0.863 & $-0.137^{* * *}$ & -0.005 \\
8 & 452.5 & 1.000 & 0.874 & $-0.126^{* * *}$ & 0.008 \\
9 & 743.0 & 1.000 & 0.924 & $-0.075^{* * *}$ & $0.037^{* * *}$ \\
10 & $2,616.8$ & 1.000 & 0.946 & $-0.054^{* * *}$ & $0.048^{* * *}$ \\
\hline
\end{tabular}

Note: This table presents the average stock market participation 1 year before, 3 years after, the difference in participation, and difference in differences in participation around the sudden inheritance by deciles of inherited wealth. Difference in differences is the difference between the sudden inheritance sample and a matched sample of individuals with the same age, gender, length of education, and rank (vigintile) of both income and wealth distribution (see Table 3). Inherited wealth is in thousand year $2000 \mathrm{DKR}$. ***, **, and * denote significance at the $1 \%, 5 \%$, and $10 \%$ levels, respectively. 
Table 5. Inherited wealth and stock market entry and continued participation decisions

\begin{tabular}{|c|c|c|c|c|}
\hline \multirow[t]{2}{*}{ Decision } & \multicolumn{2}{|c|}{ Entry } & \multicolumn{2}{|c|}{ Continued participation } \\
\hline & (1) & (2) & (3) & (4) \\
\hline Inherited wealth & $\begin{array}{l}0.1230^{* * *} \\
(0.0054)\end{array}$ & $\begin{array}{c}0.2263^{* * *} \\
(0.0081)\end{array}$ & $\begin{array}{c}0.0035 \\
(0.0035)\end{array}$ & $\begin{array}{c}0.0244^{* * *} \\
(0.006)\end{array}$ \\
\hline Inherited wealth squared & & $\begin{array}{c}-0.0141^{* * *} \\
(0.0009)\end{array}$ & & $\begin{array}{c}-0.0008^{* * *} \\
(0.0002)\end{array}$ \\
\hline Preference shifters & Yes & Yes & Yes & Yes \\
\hline Year fixed-effects & Yes & Yes & Yes & Yes \\
\hline $\begin{array}{l}\mathrm{N} \\
\text { Adj. R-squared }\end{array}$ & $\begin{array}{c}13,463 \\
0.040\end{array}$ & $\begin{array}{c}13,463 \\
0.056\end{array}$ & $\begin{array}{l}3,728 \\
0.001\end{array}$ & $\begin{array}{l}3,728 \\
0.001\end{array}$ \\
\hline
\end{tabular}

Note: The dependent variable is the difference in differences in stock market participation around the sudden inheritance. Difference in differences is the difference between the change in the treatment group receiving windfall wealth and a matched control sample. The matched sample consists of individuals of the same age, gender, length of education, and rank (vigintile) of both income and wealth distribution. Inherited wealth is measured in million year 2000 DKR. Inherited wealth squared is the square of inherited wealth. Preference shifters include controls (indicator variables) for changes in marital status, family size, and education. Standard errors are in parentheses. $* * *, * *$, and $*$ denote significance at the $1 \%, 5 \%$, and $10 \%$ levels, respectively. 
Table 6. Inherited wealth and the size of fixed entry costs

\begin{tabular}{|c|c|c|c|c|}
\hline \multirow[t]{2}{*}{ Decision } & \multicolumn{4}{|c|}{ Entry } \\
\hline & (1) & (2) & (3) & (4) \\
\hline Inherited wealth & $\begin{array}{c}0.6028^{* * *} \\
(0.0470)\end{array}$ & $\begin{array}{l}0.3251^{* * *} \\
(0.0375)\end{array}$ & $\begin{array}{c}0.2250^{* * *} \\
(0.0082)\end{array}$ & $\begin{array}{c}0.2184^{* * *} \\
(0.0084)\end{array}$ \\
\hline Inherited wealth squared & $\begin{array}{c}-0.0252^{* * *} \\
(0.0077)\end{array}$ & $\begin{array}{c}-0.0441^{* * *} \\
(0.0074)\end{array}$ & $\begin{array}{c}-0.0140^{* * * *} \\
(0.0009)\end{array}$ & $\begin{array}{c}-0.0136^{* * *} \\
(0.0009)\end{array}$ \\
\hline Age & $\begin{array}{c}0.0001 \\
(0.0003)\end{array}$ & & & \\
\hline Inherited wealth $*$ age & $\begin{array}{c}-0.0084^{* * *} \\
(0.0010)\end{array}$ & & & \\
\hline Inherited wealth squared $*$ age & $\begin{array}{c}0.0003 \\
(0.0002)\end{array}$ & & & \\
\hline Years of schooling & & $\begin{array}{c}0.0052^{* * *} \\
(0.0011)\end{array}$ & & $\begin{array}{c}0.0037^{* * *} \\
(0.0010)\end{array}$ \\
\hline $\begin{array}{l}\text { Inherited wealth } * \text { years of } \\
\text { schooling } \\
\text { Inherited wealth squared } * \\
\text { years of schooling }\end{array}$ & & $\begin{array}{c}-0.0078^{* * *} \\
(0.0022) \\
0.0019^{* * *} \\
(0.0005)\end{array}$ & & \\
\hline Financially literate & & & $\begin{array}{c}0.0967^{* * *} \\
(0.0231)\end{array}$ & $\begin{array}{c}0.0847^{* * *} \\
(0.0233)\end{array}$ \\
\hline $\begin{array}{l}\text { Inherited wealth * financial } \\
\text { literate } \\
\text { Inherited wealth squared } * \\
\text { financially literate }\end{array}$ & & & $\begin{array}{c}-0.0285 \\
(0.0432) \\
0.0017 \\
(0.0044)\end{array}$ & $\begin{array}{c}-0.0222 \\
(0.0433) \\
0.0012 \\
(0.0044)\end{array}$ \\
\hline Preference shifters & Yes & Yes & Yes & Yes \\
\hline Year fixed effects & Yes & Yes & Yes & Yes \\
\hline $\mathrm{N}$ & 13,463 & 13,463 & 13,463 & 13,463 \\
\hline Adj. R-squared & 0.067 & 0.063 & 0.062 & 0.063 \\
\hline
\end{tabular}

Note: The dependent variable is the difference in differences in stock market participation 1 year before and 3 years after the sudden inheritance. Difference in differences is the difference between the change in the treatment group receiving windfall wealth and a matched control sample. The matched sample consists of individuals of the same age, gender, length of education, and rank (vigintile) of both income and wealth distribution. Inherited wealth is measured in million year 2000 DKR. Inberited wealth squared is the square of inherited wealth. Age is measured in years. Financial literate is an indicator taking the value 1 if the individual has a university degree in economics, finance, or a related field, or obtained, through an apprenticeship in the financial industry, knowledge about financial markets. Preference shifters include controls (indicator variables) for changes in marital status, family size, and education. Standard errors are in parentheses. ***, **, and * denote significance at the $1 \%, 5 \%$, and $10 \%$ levels, respectively. 
Table 7. The effect of investment inertia: Alternative event windows

\begin{tabular}{|c|c|c|c|c|c|c|}
\hline \multirow{3}{*}{$\begin{array}{l}\text { Decision } \\
\text { Event window }\end{array}$} & \multicolumn{3}{|c|}{ Entry } & \multicolumn{3}{|c|}{ Continued participation } \\
\hline & (1) & $(2)$ & (3) & (4) & (5) & (6) \\
\hline & $(-1 ;+1)$ & $(+1 ;+3)$ & $(+3 ;+5)$ & $(-1 ;+1)$ & $(+1 ;+3)$ & $(+3 ;+5)$ \\
\hline Inherited wealth & $0.2263^{* * *}$ & $0.0945^{* * *}$ & 0.0071 & $0.012^{* *}$ & $0.0097^{*}$ & -0.0015 \\
\hline \multirow{2}{*}{$\begin{array}{l}\text { Inherited wealth } \\
\text { squared }\end{array}$} & $-0.0141^{* * *}$ & $-0.0053^{* * *}$ & 0.0000 & $-0.0003^{*}$ & $-0.0004^{* *}$ & 0.0000 \\
\hline & $(0.0009)$ & $(0.0008)$ & $(0.0048)$ & $(0.0002)$ & $(0.0002)$ & $(0.0002)$ \\
\hline Preference shifters & Yes & Yes & Yes & Yes & Yes & Yes \\
\hline Year fixed-effects & Yes & Yes & Yes & Yes & Yes & Yes \\
\hline $\mathrm{N}$ & 13,463 & 12,064 & 7,339 & 3,728 & 3,425 & 1,970 \\
\hline Adj. R-squared & 0.059 & 0.020 & 0.002 & 0.003 & 0.010 & 0.010 \\
\hline
\end{tabular}

Note: The dependent variable is the difference in differences in stock market participation for alternative event windows. Difference in differences is the difference between the change in the treatment group receiving windfall wealth and a matched control sample. Column 1 through 3 is entry into the stock market. Column 4 through 6 is exit decisions out of the stock market. The matched sample consists of individuals of the same age, gender, length of education, and rank (vigintile) of both income and wealth distribution. Inherited wealth is measured in million year 2000 DKR. Inherited wealth squared is the square of inherited wealth. Preference shifters include controls (indicator variables) for changes in marital status, family size, and education. Standard errors are in parentheses. ${ }^{* * *},{ }^{* *}$, and $*$ denote significance at the $1 \%, 5 \%$, and $10 \%$ levels, respectively. 
Table 8. The effect of procrastination: Windfall cash versus windfall stocks

\begin{tabular}{lccc}
\hline Decision & \multicolumn{3}{c}{ Entry } \\
\cline { 2 - 4 } & $\mathbf{( 1 )}$ & $\mathbf{( 2 )}$ & $\mathbf{( 3 )}$ \\
\hline Inherited wealth & $0.1667^{* * *}$ & \\
Inherited wealth squared & $(0.0085)$ & \\
Inherited estate holds stocks (0/1) & $-0.0101^{* * *}$ & & \\
& $(0.0009)$ & & $0.1220^{* * *}$ \\
Inherited wealth excluding stocks & $0.1267^{* * *}$ & & $(0.0069)$ \\
& $(0.0066)$ & $0.1925^{* * *}$ & $0.1550^{* * *}$ \\
Inherited wealth excluding stocks squared & & $(0.0089)$ & $(0.0091)$ \\
Value of inherited stocks & & $-0.0128^{* * *}$ & $-0.0103^{* * *}$ \\
Value of inherited stocks squared & & $(0.0010)$ & $(0.0010)$ \\
& & $0.6331^{* * *}$ & $0.2973^{* * *}$ \\
Preference shifters & & $(0.0527)$ & $(0.0555)$ \\
Year fixed-effects & & $-0.1958^{* * *}$ & $-0.0600^{* *}$ \\
$\mathrm{~N}$ & & $(0.0293)$ & $(0.0300)$ \\
Adj. R-squared & Yes & Yes & Yes \\
\hline
\end{tabular}

Note: The dependent variable is the difference in differences in stock market participation 1 year before and 3 years after the sudden inheritance. Difference in differences is the difference between the change in the treatment group receiving windfall wealth and a matched control sample. The matched sample consists of individuals of the same age, gender, length of education, and rank (vigintile) of both income and wealth distribution. Inherited wealth, inherited wealth excluding stocks, and value of inherited stocks are measured in million year 2000 DKR. Inberited estate beld stocks (0/1) is an indicator variable for whether the estate held stocks. Preference shifters include controls (indicator variables) for changes in marital status, family size, and education. Standard errors are in parentheses. ${ }^{* * *}, * *$, and $*$ denote significance at the $1 \%, 5 \%$, and $10 \%$ levels, respectively. 
Table 9. Interpretation: Are non-participants holding financial wealth at all?

\begin{tabular}{|c|c|c|c|c|c|c|c|c|}
\hline & \multicolumn{5}{|c|}{$\begin{array}{l}\text { Distribution of change in financial } \\
\text { wealth relative to pre-inheritance }\end{array}$} & \multicolumn{3}{|c|}{$\begin{array}{l}\text { Average financial wealth } \\
\qquad(1,000 \mathrm{DKR})\end{array}$} \\
\hline & $<25 \%$ & $25-50 \%$ & $50-75 \%$ & $\begin{array}{l}75 \%- \\
100 \%\end{array}$ & $>100 \%$ & $\begin{array}{c}\text { Pre- } \\
\text { inheritance } \\
(\text { Year -1) }\end{array}$ & $\begin{array}{c}\text { Post- } \\
\text { inheritance } \\
(\text { Year }+3)\end{array}$ & Difference \\
\hline \multicolumn{9}{|l|}{ A. All } \\
\hline $\begin{array}{l}\text { Individual } \\
\text { Household }\end{array}$ & $\begin{array}{l}0.402 \\
0.388\end{array}$ & $\begin{array}{l}0.053 \\
0.063\end{array}$ & $\begin{array}{l}0.039 \\
0.051\end{array}$ & $\begin{array}{l}0.036 \\
0.041\end{array}$ & $\begin{array}{l}0.471 \\
0.457\end{array}$ & $\begin{array}{l}36.5 \\
88.8\end{array}$ & $\begin{array}{c}68.3 \\
296.4\end{array}$ & $\begin{array}{c}31.8 \\
207.6\end{array}$ \\
\hline \multicolumn{9}{|c|}{ B. Windfall wealth $>1$ million DKR } \\
\hline $\begin{array}{l}\text { Individual } \\
\text { Household }\end{array}$ & $\begin{array}{l}0.275 \\
0.217\end{array}$ & $\begin{array}{l}0.022 \\
0.051\end{array}$ & $\begin{array}{l}0.022 \\
0.032\end{array}$ & $\begin{array}{l}0.030 \\
0.046\end{array}$ & $\begin{array}{l}0.652 \\
0.655\end{array}$ & $\begin{array}{c}67.1 \\
147.1\end{array}$ & $\begin{array}{l}125.8 \\
512.0\end{array}$ & $\begin{array}{c}58.7 \\
364.9\end{array}$ \\
\hline
\end{tabular}

Note: All panels report financial wealth for beneficiaries that remain non-participants after receiving windfall wealth. Financial wealth is the sum of bonds and cash, and is reported pre-inheritance (year -1 ) and post-inheritance (year +3 ). Panel A shows individual holdings, whether Panel B shows the holdings at the household level. If bank accounts are shared within the household, the reported holding of cash at the individual level is equal to half of the total holdings at the household level. All numbers are in 2000 DKR. 
Table 10. Alternative specifications

\begin{tabular}{|c|c|c|c|c|c|c|c|c|c|c|}
\hline \multirow[t]{2}{*}{ Decision } & \multicolumn{5}{|c|}{ Entry } & \multicolumn{5}{|c|}{ Continued Participation } \\
\hline & (1) & (2) & (3) & (4) & (5) & (6) & (7) & (8) & (9) & (10) \\
\hline Sample & $\begin{array}{c}\text { Traffic } \\
\text { accidents }\end{array}$ & $\begin{array}{c}\text { Both } \\
\text { parents }\end{array}$ & $\begin{array}{c}\text { No } \\
\text { siblings }\end{array}$ & $\begin{array}{c}\text { Household } \\
\text { level }\end{array}$ & $\begin{array}{l}\text { Matching on } \\
\text { parental age }\end{array}$ & $\begin{array}{c}\text { Traffic } \\
\text { accidents }\end{array}$ & $\begin{array}{c}\text { Both } \\
\text { parents }\end{array}$ & $\begin{array}{c}\text { No } \\
\text { siblings }\end{array}$ & $\begin{array}{c}\text { Household } \\
\text { level }\end{array}$ & $\begin{array}{l}\text { Matching on } \\
\text { parental age }\end{array}$ \\
\hline Inherited wealth & $\begin{array}{c}0.2436^{* * *} \\
(0.0197)\end{array}$ & $\begin{array}{c}0.2333^{* * *} \\
(0.0250)\end{array}$ & $\begin{array}{c}0.1786^{* * *} \\
(0.0111)\end{array}$ & $\begin{array}{c}0.2321^{* * *} \\
(0.0111)\end{array}$ & $\begin{array}{c}0.2462^{* * *} \\
(0.0087)\end{array}$ & $\begin{array}{c}0.0539^{* * *} \\
(0.0200)\end{array}$ & $\begin{array}{l}0.0575^{* *} \\
(0.0299)\end{array}$ & $\begin{array}{c}0.0381^{* * *} \\
(0.0087)\end{array}$ & $\begin{array}{l}0.0125^{* *} \\
(0.0062)\end{array}$ & $\begin{array}{c}0.0295^{* * *} \\
(0.008)\end{array}$ \\
\hline Inherited wealth squared & $\begin{array}{c}-0.0140^{* * *} \\
(0.0022)\end{array}$ & $\begin{array}{c}-0.0131^{* * *} \\
(0.0017)\end{array}$ & $\begin{array}{c}-0.0102^{* * *} \\
(0.0010)\end{array}$ & $\begin{array}{c}-0.0156^{* * *} \\
(0.0019)\end{array}$ & $\begin{array}{c}-0.0152^{* * *} \\
(0.0009)\end{array}$ & $\begin{array}{c}-0.0017^{* * *} \\
(0.0006)\end{array}$ & $\begin{array}{l}-0.0030 \\
(0.0028)\end{array}$ & $\begin{array}{c}-0.0001^{* * * *} \\
(0.0003)\end{array}$ & $\begin{array}{c}-0.0003^{* * *} \\
(0.0002)\end{array}$ & $\begin{array}{c}-0.0011^{* * *} \\
(0.0003)\end{array}$ \\
\hline Preference shifters & Yes & Yes & Yes & No & Yes & Yes & Yes & Yes & No & No \\
\hline Year fixed-effects & Yes & Yes & Yes & Yes & Yes & Yes & Yes & Yes & Yes & Yes \\
\hline $\mathrm{N}$ & 2,584 & 1,058 & 4,294 & 10,386 & 11,906 & 602 & 304 & 1,620 & 3,728 & 3,057 \\
\hline Adj. R-squared & 0.065 & 0.081 & 0.063 & 0.049 & 0.066 & 0.007 & 0.009 & 0.013 & 0.001 & 0.001 \\
\hline
\end{tabular}

Note: The dependent variable is the difference in differences in stock market participation 1 year before and 3 years after around the sudden inheritance. Difference in differences is the difference between the change in the treatment group receiving windfall wealth and a matched control sample. We use four different subsamples: Accidents include household terminations caused by accidents. Both parents include household terminations in which both parents died within the year. No siblings include household terminations with a single beneficiary. Household level includes the household of the beneficiaries if the household's characteristics are stable during the evaluation period (see Section 4.4). The matched sample consists of individuals of the same age, gender, length of education, and rank (vigintile) of both income and wealth distribution in Columns 1-3, and 6-8. In Columns 4 and 9, the matched sample consists of households with the same average age, highest length of education, number of household members, and rank (vigintile) of both income and wealth distribution. In Column 5 and 10, the matched sample consists of individuals with parents of the same age in addition to the general match characteristics. Inherited wealth is measured in million year 2000 DKR. Preference shifters include controls (indicator variables) for changes in marital status, family size, and education. Standard errors are in parentheses. ***, **, and * denote significance at the 1\%, $5 \%$, and $10 \%$ levels, respectively. 